\title{
The knowledge and attitudes of
}

traditional birth attendants towards

HIV/AIDS and their beliefs related to

perinatal care: a study conducted in

KwaZulu Natal

\author{
GG Mchunu, M Cur, School of Nursing, University of Natal \\ BR Bhengu, PhD, School of Nursing, University of Natal
}

\section{Abstract}

Traditional birth attendants (TBAs) are still mainly being utilized in the rural areas even in the presence of the formal health care facilities. Studies reveal that the utilization of TBAs is beneficial in some other contexts with some support and supervision from the western health sector. In order to develop further training for TBAs the researchers deemed it necessary to assess their knowledge, attitudes and beliefs related to HIV/AIDS, prenatal care, delivery and postnatal care.

This was a survey of an identified group of TBAs who had already received some training and were currently practicing in the catchment areas. Five Primary health care (PHC) clinics from Abaqulusi subdistrict in Zululand Health District, Kwa-Zulu Natal Province, were selected as sites for the focus groups. A total of 57 TBAs participated in focus groups and completed a questionnaire.

The HIV/AIDS knowledge questionnaire consisted of 16 questions about transmission, symptoms, course of the disease and its risk factors. An assessment tool was used to assess attitudes, beliefs and practice in relation to pregnancy, delivery and postnatal care.

The results of this study demonstrated that the TBAs have a good knowledge of what they are doing.

\section{Abstrak}

Tradisionele Geboortehulpe (TGH) word steeds in plattelandse gebiede gebruik, alhoewel formele gesondeheidsdienste beskikbaar is. Studies toon dat hierdie TGH goed gebruik kan word indien hulle deur die westerse dienste ondersteun word en onder hul toesig werk. Die navorsers het die kennis, houdings en oortuigings van hierdie groep met betrekking tot VIGS, voorgeboorte sorg, geboorte en nageboorte-sorg ondersoek met die oog op die ontwikkeling van verdere onderrig.

Hierdie artikel beskryf 'n oorsig van 'n geidentifiseerde groep TGHs wat reeds beperkte onderrig ontvang het en steeds praktiseer in die opvangs area. Vyf primêre sorg klinieke in die Abaqulusi sub-distrik van Zululand distrik, KwaZulu-Natal, is geselekteer vir die fokusgroepe. ' $n$ Totaal van 57 TGH het in die fokus groepe deelgeneem en die vraelys voltooi.

Die MIV/VIGS kennis vraelys het bestaan uit 16 vrae in verband met oordrag, simptome, verloop van die siekte en risiko-faktore. 'n Evalueringsinstrument is gebruik om houdings, oortuigings en praktyke in verband met swangerskap, geboorte en postnatale sorg te ondersoek. Die resultate toon dat TGH' ' $n$ goeie kennis het van wat hul doen.

\section{Background}

Traditionally African births, including prenatal and postnatal care, took place at home, supervised by at least one older, trusted female member of the family or community. This was part of the comprehensive socialization process of the woman in African culture through her lifespan (Chalmers, 1990: 15). The influence and acceptability of these females, known as Traditional Birth Attendants (TBAs) continue to exist amongst people in remote rural areas and even when formal health services are available. Pregnant women in rural communities worldwide still rely on TBAs for advice throughout their pregnancies. Such advice includes dietary information, sexual activities and medication to be taken during pregnancy. A study conducted by Davies, Yin Nu, Oum and Waisi (1992: 1) in North- 
East Thailand revealed that $49 \%$ of all mothers in sampled villages who had had babies the previous year had received the services of TBAs in one form or another.

In South Africa, as well, it has been found that between 60 and $80 \%$ of the South African population visit traditional healers before attending western/formal health care services (Pretorius, 1999: 250). Asghar (2001: 1) argues that ninety nine percent $(99 \%)$ of all maternal mortality occurs in developing countries with limited resources and shattered economies. Therefore TBAs are consulted as a matter of necessity owing to the inaccessibility of Western health care services geographically, financially, organizationally or culturally especially in rural areas, whereas in urban areas it is a matter of preference (Asghar, 2001:55; http://www.mariestopes.org.uk/case study1.html: Pretorius, 1999: 251)

Some authors have identified advantages of TBAs over Western midwives, such as a close personal relationship with the client, which is attributed to their speaking the local language and sharing cultural and health beliefs with women http://bmi.com/cgi/content/full/324/7331/222 Walraven, 2002: 224), thus facilitating communication. Long acquaintance, understanding of the context, emotional support, and belief in their kinship, trust, and assurance of privacy are other advantages (Ehlers, 2000: 32). TBAs cannot, however, be automatically incorporated with Western health care. Some authors have observed flaws in the practice of TBAs such as poor hygienic practices and infection control, for example, lack of hand washing, unsafe cutting of the cord threatening the safety of the baby, interference with labour, and harmful traditional practices such as taking oxytocic agents (http://www.mariestopes.org.uk/ case studv1.html ; Sahachowdhury, 2000: 6).

Worlwide, one million women infected with HIV are estimated to deliver their babies without the help of professional health care workers (Bulterys, Fowler, Shaffer, Tih, Greenbreg, Karita, Coovadia \& De Cock, 2002: 222). The findings of a survey conducted by Habimana, Bulterys, Usabuwera, Chao \& Saah (2002: 1) to investigate the risks of occupationally acquired HIV infection among TBAs in Rwanda showed that ninety one percent of TBAs had never used gloves during their work. Bulterys et al (2002:222) further argue that infant mortality in eastern and southern Africa is one third to two thirds higher than it would have been in the absence of HIV/AIDS. These authors concluded that TBAs could play a key role in the prevention and control of HIV/AIDS in rural communities, if properly trained. More rigorous training and supervision is needed in order to help fight the AIDS pandemic in terms of confidential HIV counselling and testing, including short courses on retroviral drugs to prevent unnecessary maternal and foetal deaths (Bulterys et al, 2002:224). Walraven (2002: 225), however, asserts that it would be more difficult for the women to discuss such sensitive issues with women from their own communities than it would be with an outsider. This observation warrants better understanding of women who accept TBAs and those who resist them, and also training TBAs on protecting patient confidentiality.
The identified skills needed for the training of TBAs are safety in their practice, non-interference during perinatal care, early recognition of obstetric complications and referral, some obstetric emergency care, and avoiding unsafe traditional practices. Furthermore, the government should provide back-up services like the provision of a well equipped and appropriately staffed referral network, transport for high- risk mothers and even delivery kits to promote hygiene (Asghar, 1999:57; http:// www.mariestopes.org.uk/traditional birth attendants.html. Asghar (1999: 57) has identified further barriers to this support such as access to health care centres, resistance to TBAs by the Western health care personnel, and financial constraints, but believes that it should be possible to supply free ambulances.

\section{Problem statement}

From the above discussion it appears that TBAs are still being utilized, mainly in the rural areas, even in the presence of the health care facilities. In South Africa, fifty three percent $(53 \%)$ of the population lives in rural areas (Department of Health, 1997: 11). Studies reveal that the utilization of TBAs is beneficial in some contexts with some support and supervision from the Western health sector. Although TBAs are at risk of occupational exposure to blood contact, they can play a major role in the prevention of HIV transmission. It appears that the government cannot ignore this sector of health care, but should rather facilitate it towards safe and affordable practice. In keeping with this proposal, the authors deemed it necessary to assess the knowledge and attitudes of TBAs towards HIV/AIDS, including their beliefs related to prenatal, delivery and postnatal care. These are important issues in the practice of maternal and child health.

\section{Purpose and objectives}

In order to develop further training, it was necessary to assess the existing knowledge, attitudes and beliefs of TBAs related to HIV/ AIDS and to perinatal care.

The objectives were:

1) To assess TBAs' knowledge of perinatal care.

2) To establish TBAs' extent of practice during perinatal care.

3) To determine TBAs' beliefs and rituals influencing their practice.

4) To establish TBAs' knowledge of and attitudes towards HIV/AIDS.

\section{Operational definitions}

Traditional Birth Attendants: These are respected family or community members, usually females, who are self-taught or informally trained to conduct the birthing process in the rural settings. They also provide advice and care relating to prenatal care, delivery and postnatal care.

Knowledge: This refers to information related to prenatal assessment for gestational period, risk factors for the mother during pregnancy, the response of TBAs in the event of any risk factor related to perinatal period, including HIV/ 
AIDS.

Attitude: This refers to the way TBAs view people with HIV/AIDS.

Perinatal care: It is the care given during the prenatal, delivery and postnatal period.

\section{Methodology}

A quantitative research approach was adopted using a nonexperimental descriptive survey, on an identified group of TBAs. Cresswell, (2003:153) and Neuman (1997: 228) assert that surveys produce quantitative information about the identified population, and are appropriate for exploration of, among others, the population's attitudes, beliefs and opinions. Since this study aimed at exploring the beliefs of TBAs and their attitudes, this design was therefore seen to be appropriate.

\section{Setting}

Five primary health care clinics from the Abaqulusi subdistrict of Zululand health district (formerly known as Ulundi district), in KwaZulu Natal, were selected as study sites. These were Bhekumthetho, Ntababomvu, Siyakhathala, Hartland and Tholakele clinics, which were selected partly because they were accessible to all TBAs. This area was also seen as relatively typical of rural areas in Kwa Zulu Natal, where health care users have to walk long for long distances due to limited infrastructure.

\section{Sampling}

The respondents were selected using purposive sampling. The PHC coordinators identified TBAs in the area who had received training from the local midwife. All TBAs who had received one year of training from a midwife, and were currently practising in the catchment areas of the four clinics, were recruited for participation in this research. A total of 57 TBAs participated in the five groups and completed the questionnaires.

\section{Data collection techniques}

Individual interviews were conducted to collect demographic data, knowledge and attitudes, while focus groups were utilized for data on beliefs, rituals and practices related to perinatal care. The respondents were assisted by two trained fieldworkers to fill in the questionnaires because of the problem of illiteracy in the area. The TBAs were asked to answer a series of true/false questions, which dealt with risk signs for the mother during pregnancy. They were then asked a series of open-ended questions to assess their attitudes, beliefs and practices related to pregnancy, delivery, and postpartum care. All the respondents $(n=56)$ were asked to complete an HIV/AIDS knowledge questionnaire consisting of 16 statements about transmission, symptoms, course of disease and risk factors. They then completed a questionnaire that assessed their beliefs and attitudes towards HIV/AIDS. The respondents ranked the answers to a series of statements concerning HIV/AIDS, on a scale of $1-3$, where $1=$ agree, $2=$ don't know/uncertain and $3=$ disagree .

For the focus groups, an interview guide was prepared and translated into Zulu, and was then pilot-tested on three TBAs. The guide was used to maintain the same method and style of questioning in all groups. Fifty-six TBAs were interviewed, using five focus groups. Trained TBAs of Ulundi Distirct, KwaZulu-Natal, participated in focus groups organized by researchers. The goal of the researchers was to gather information on the current knowledge/practices, attitudes, and beliefs of TBAs and women related to pregnancy and childbirth. An interview guide was used to collect these baseline data for the focus groups. A small focus group, lasting 1.5 to 2 hours, was held in each clinic to collect data. Once the purpose of the session was explained, the informants were given a chance to get to know the researchers ("warming up"), as it was observed that many were shy and, as a result, not all of them were actively participating. One researcher interacted with the interviewees while the other recorded their responses.

\section{Data analysis}

Data was analysed using Epidemiological Information (Epi Info) statistical analysis software. Descriptive statistics were utilized using frequencies, percentages and tables.

\section{Ethical consideration}

Permission was sought from Amakhosi in each area, the health district director, and sub-district coordinators, including registered nurses in charge of the clinics. The identified TBAs who had conducted deliveries were also approached for their permission to participate in the study by giving verbal consent before being interviewed.

\section{Findings}

Findings are presented according to demographics, knowledge of and attitudes towards HIV/AIDS, knowledge and practice of peri-natal care and beliefs related to perinatal care.

\section{Demographics}

Demographics include (a) perceived role (b) level of literacy (c) religion (d) parity (e) experience with birthing and (f) practice.

\section{Perceived role}

All respondents $(100 \% ; 56 / 56)$ identified themselves as TBAs from Ulundi District of KwaZulu-Natal. Forty-three percent (24/56) were between the ages of 50 and 59 years; $25 \%$ were between 40 and 48 years and $13 \%$ were between 61 and 68 years of age. Forty-four percent $(25 / 56)$ indicated that they had more than 10 years of experience and 96\% (54/56) of respondents indicated that they had undergone training. Ninety-five percent (53/56) indicated that their training lasted "one year". Twenty-six percent of those who responded (12/ 47) had completed their training at Ntababomvu clinic, and $29 \%(16 / 56)$ worked out of this location. 


\section{Level of literacy}

Only $83 \%(47 / 56)$ of the TBAs responded to this question whether they could read or not and 94\% (44/47) of those who responded could read. When asked if they could write $94 \%(52 / 56)$ responded to the question, of those who responded, 92\% (48/52) could write. All of those who responded $(93 \% ; 52 / 56)$ spoke Zulu.

\section{Religion}

Fifty-five percent (31/56) identified their religion as "Zion", $7.1 \%$ (4/56) Roman Catholic Church, 5.4\% (3/56) Church of God, 3.6\% (2/56) belonged to St. Apostolic Faith Mission, the Methodist Church or the Lutheran Church. Almost two percent $(1.8 \% ; 1 / 56)$ belonged to the United Reformed Church, the Independence Church or the Anglican Church. The remaining $10.7 \%(6 / 56)$ belonged to churches classified as "other".

\section{Experience of TBAs}

Fifty-seven percent of TBAs (30/53) had assisted with five or fewer live births in the past year, while 26\% (14/53) had assisted with between 6 to 10 live births, and 17\% (9/53) had assisted with between 11 and 30 live births. Eight percent (4/53) of respondents had assisted with between 1 and 3 stillbirths, and 4\% (2/53) had assisted with at least 2 deliveries that resulted in neonatal fatalities.

\section{Practice of TBAs}

Fifty three percent of TBAs (29/55) said, "women come me if they think they're pregnant" $86 \%$ (47/55) claimed that they do "refer women to a nurse or doctor" and $84 \%$ (47/56) revealed that they do "refer women to a hospital or clinic" (Table 1). Ninety-three percent of respondents (52/56) mentioned that people who need their services often "fetch the TBA from her home". Ninety-four percent of TBAs (51/54) said that they do "report the births or record them"
(Table 1). Ninety-seven percent (53/55) said that they were not paid for their services and $4 \%(2 / 56)$ indicated that they received "presents" (Table 1 ).

\section{Knowledge of HIV/AIDS}

All respondents $(100 \%)$ indicated that AIDS, "is caused by a virus", and that it "destroys a person's disease-fighting ability". All TBAs (100\%) also indicated that "I can get AIDS from coming into contact with another person's body fluids (blood, semen, vaginal fluids, and breast-milk)", and "If I use dirty injection needles, I can get AIDS". Ninetyeight percent of respondents indicated that, "When I have AIDS and I am expecting a baby, my baby may get it too when it is born". Ninety-seven percent stated, "AIDS is transmitted through sexual intercourse". Forty-six percent of respondents reported "you can get AIDS from mosquito bites". Eighty-six percent indicated that "during menstruation, women get AIDS more easily", and 95\% (54/57) stated that "women who have sex with other women have a high risk of getting AIDS". Eighty-six percent of the TBAs surveyed indicated "it's totally impossible to get AIDS from sexual intercourse if you use a condom".

Ninety-eight percent of respondents stated that "common symptoms of AIDS are swelling of glands and fever", and $70 \%$ also said that, "you can always tell when someone has AIDS". Ninety-seven percent of TBAs indicated, "It is possible to have HIV and not know it for up to 10 years" and that "a blood test can tell if you have AIDS". Ninetyeight percent of the TBAs indicated that "if I have AIDS I will die" and $91 \%$ stated that "most people suffering from AIDS die within 2-5 years of getting the disease". Four percent of respondents achieved a score of 9 correct responses out of 16 on the HIV/AIDS Knowledge questionnaire; while $32 \%$ achieved a score of 10 , and $37 \%$ achieved a score of 11 .

\section{Table 1: TBA history of practice}

\begin{tabular}{|c|c|c|c|c|c|c|}
\hline Question & Missing Responses & Total Responses (N) & $\begin{array}{l}\text { Re } \\
\text { Yes } \\
\mathbf{n}\end{array}$ & & $\begin{array}{l}\text { No } \\
\text { n }\end{array}$ & $\%$ \\
\hline $\begin{array}{l}\text { Do women come to see you if they } \\
\text { think they're pregnant? }\end{array}$ & 1 & 55 & 29 & 52.7 & 26 & 47.3 \\
\hline $\begin{array}{l}\text { Do you ever refer the women to a nurse } \\
\text { or doctor? }\end{array}$ & 1 & 55 & 47 & 85.5 & 8 & 14.5 \\
\hline $\begin{array}{l}\text { Do you ever refer the women to a } \\
\text { hospital or clinic? }\end{array}$ & 0 & 56 & 47 & 83.9 & 9 & 16.1 \\
\hline Are you paid for your services? & 1 & 55 & 2 & 3.6 & $\mathbf{5 3}$ & 96.4 \\
\hline $\begin{array}{l}\text { Do you report the births to anyone } \\
\text { or record them? }\end{array}$ & 2 & 54 & 51 & 94.4 & 3 & 5.6 \\
\hline
\end{tabular}




\begin{tabular}{|c|c|c|c|c|c|c|}
\hline \multirow[t]{2}{*}{ Question } & \multicolumn{2}{|c|}{$\begin{array}{l}\text { Response }(\mathrm{N}=57) \\
\text { Agree }\end{array}$} & \multicolumn{2}{|c|}{ Don't Know } & \multicolumn{2}{|c|}{ Disagree } \\
\hline & $\mathbf{n}$ & $\%$ & $\mathbf{n}$ & $\%$ & $\mathbf{n}$ & $\%$ \\
\hline $\begin{array}{l}\text { 1. It's important to care for/be helpful to someone who has } \\
\text { HIV/AIDS. }\end{array}$ & 53 & 93.0 & 2 & 3.5 & 2 & 3.5 \\
\hline $\begin{array}{l}\text { 2. People who have HIV/AIDS should be allowed to work in } \\
\text { places such as: } \\
2.1 \text { Schools }\end{array}$ & 35 & 61.4 & 9 & 15.8 & 13 & 22.8 \\
\hline 2.2 Where they sell food & 31 & 54.4 & 8 & 14.1 & 18 & 31.6 \\
\hline $\begin{array}{l}\text { 3. } 1 \text { have a negative attitude toward men having sex with } \\
\text { other men because of this HIV/AIDS epidemic. }\end{array}$ & 38 & 66.7 & 3 & 5.3 & 16 & 28.1 \\
\hline $\begin{array}{l}\text { 4. If you have HIV/AIDS, you got it because you did not } \\
\text { control yourself well sexually. }\end{array}$ & 43 & 75.4 & 2 & 3.6 & 12 & 21.1 \\
\hline $\begin{array}{l}\text { 5. Men and women should be equal in society - it should } \\
\text { not matter what their sex (gender) is. }\end{array}$ & 44 & 77.2 & 7 & 12.3 & 6 & 10.5 \\
\hline $\begin{array}{l}\text { 6. Patients with HIV/AIDS have as much right to good health/ } 4 \\
\text { medical care as anyone else. }\end{array}$ & 46 & 80.7 & 5 & 8.8 & 6 & 10.5 \\
\hline $\begin{array}{l}\text { 7. I am afraid that other people will scold me when/if I have } \\
\text { HIV/AIDS. }\end{array}$ & 37 & 64.9 & 7 & 12.3 & 13 & 22.8 \\
\hline $\begin{array}{l}\text { 8. Having sex with someone of the same sex (gender) is } \\
\text { wrong. }\end{array}$ & 33 & 57.9 & 9 & 15.8 & 15 & 26.3 \\
\hline $\begin{array}{l}\text { 9. Having sex with someone of the same sex (gender) is not } \\
\text { good for your health. }\end{array}$ & 35 & 61.4 & 5 & 8.8 & 17 & 29.8 \\
\hline $\begin{array}{l}\text { 10. HIV/AIDS is God's punishment for people who live wrong } 4 \\
\text { lives. }\end{array}$ & 40 & 70.2 & 10 & 17.5 & 7 & 12.3 \\
\hline $\begin{array}{l}\text { 11. I will be very upset if I have to look after someone who } \\
\text { has HIV/AIDS. }\end{array}$ & 36 & 63.2 & 2 & 3.5 & 19 & 33.3 \\
\hline $\begin{array}{l}\text { 12. It is unfair that government is spending so much money } \\
\text { on trying to help people with HIV/AIDS whilst others who do not } \\
\text { have AIDS are also suffering. }\end{array}$ & $\begin{array}{l}27 \\
\text { ot }\end{array}$ & 47.4 & 3 & 5.3 & 27 & 47.4 \\
\hline $\begin{array}{l}\text { 13. It would be upsetting to be alone with someone who is } \\
\text { known to have sex with other people of the same sex (gender). }\end{array}$ & 35 & 61.4 & 3 & 5.3 & 19 & 33.3 \\
\hline $\begin{array}{l}\text { 14. If I learned someone I know has HIV/AIDS it would be hard } 3 \\
\text { for me to go on with an relationship with that person. }\end{array}$ & & 54.4 & 6 & 10.6 & 20 & 35.1 \\
\hline
\end{tabular}

\section{Attitudes towards HIV/AIDS}

Ninety-three percent (53/57) of TBAs agreed with the statement that, "it's important to care for/to be helpful to someone who has AIDS"; whereas 63\% (36/57) of respondents also agreed with the statement that, "I will be very upset if I have to look after someone who has AIDS" (Table 2). Fifty-four percent (31/57) of TBAs also agreed with the statement, "if I learned someone I know has AIDS, it would be hard for me to go on with any relationship with that person". Sixty-five percent (37/57) of the respondents agreed with the statement, "I am afraid that other people will scold me when/if I have AIDS". Seventy-five percent (43/57) of the TBAs surveyed agreed with the statement that, "if you have AIDS, you got it because you did not control yourself sexually" and 75\% (40/57) of respondents 
agreed with the statement, "AIDS is God's punishment for people who live wrong lives".

Sixty seven percent (38/57) of TBAs agreed with the statement, "I have a negative attitude towards men having sex with other men because of this AIDS epidemic". Fiftyeight percent (33/57) of respondents agreed that, "having sex with someone of the same sex is wrong", while $61 \%$ (35/ 57 ) of respondents agreed that "having sex with someone of the same sex is not good for your health" and that, "it would be upsetting to be alone with someone who is known to have sex with other people of the same sex".

Eighty-one percent (46/57) of respondents agreed that "patients with AIDS have as much right to good health/medical care as anyone else". An equal number of respondents $47 \%$ (27/57) agreed and disagreed, respectively, with the statement that, "it is unfair that government is spending so much on trying to help people with AIDS whilst others who do not have AIDS are suffering".

Finally, the majority of respondents agreed that "people who have AIDS should be allowed to work in places such as schools $(63 \% ; 35 / 57)$ and where food is sold $(54 \% ; 31 /$ 57) “.

\section{Knowledge of Prenatal, delivery and postnatal care}

The TBAs were asked to answer a series of true/false questions, which dealt with risk signs for the mother during pregnancy (Table 3). Ninety-six percent (54/56) of the respondents identified "bleeding from the vagina" as a risk sign for the mother, while "swelling of the face and hands" (50/55) and, "shortness of breath"(51/56) were identified as risk signs by $91 \%$ of respondents. Ninety-eight percent (52/53) stated that, "emotional highs and lows" were also a risk sign for the mother. A resting pulse over 100 beats/ minute was identified as a risk sign by $96 \%(53 / 55)$ of respondents, while $89 \%$ of respondents $(31 / 35)$ indicated that "back pain along the spine" is a risk sign. Finally, $96 \%$ of TBAs identified "pain along the sides of the spine" as a risk sign for the mother. When asked what they would do if they found any of these risk signs, 93\% (50/54) of TBAs reported that they would "refer the mother to a clinic/hospital" (Table 4).

The three most common responses to the question: "how do you know that the mother is ready to deliver?" were "the stomach drops" (21\%; 11/53); "engagement" (13\%; 7/ $53)$ and "check [vagina] with fingers" $(8 \% ; 4 / 53)$. The three most common responses to the question, "how long after the baby is delivered should the placenta be expelled?" included, "a short time" (14\%; 6/43), "a few seconds" (14\%; $6 / 43)$, and " 10 minutes or more" $(9 \% ; 4 / 43)$. It appears that this question was also misinterpreted by some TBAs; since many explained how they know that the placenta has been delivered. Sixty-two percent of respondents (34/55) indicated that they do conduct abnormal or complicated deliveries; including "leg extensions" (33\%; 17/52) and breech deliveries (10/52). Forty-five percent of respondents (25/ 53) replied that in the case of a perineal tear, they would "send the mother to a hospital/clinic" to facilitate healing.

\section{Assessment of practice during Prenatal, delivery and postnatal care Prenatal Care}

Eighty-three percent (43/52) of TBAs reported that they do conduct prenatal check-ups. Forty-four percent (20/45) indicated that these visits are conducted every month, while $40 \%(18 / 45)$ said they are conducted every week. Ninetyeight percent (55/56) of the TBAs surveyed stated that they do advise their clients to go to a clinic for immunizations; and $96 \%(51 / 53)$ stated that they know that the immunizations are for tetanus prevention.

\section{Preparation for Birthing}

When asked, "At what stage in the birth does the TBA arrive?", $45 \%$ (25/56) did not respond, 38\% (21/56) replied with, "stage 1", $11 \%(6 / 56)$ said "stage 2" and 7\% (5/56) stated, "stage 3". Ninety-eight percent of the TBAs surveyed (55/56) indicated that, " a clean birth area (which has been washed down with soap and water) is selected", and

\section{Table 3: Knowledge assessment: Risk factors for the mother during pregnancy}

\begin{tabular}{|c|c|c|c|c|c|c|}
\hline Question & $\begin{array}{l}\text { Missing } \\
\text { Responses }\end{array}$ & $\begin{array}{l}\text { Total } \\
\text { Responses (n) }\end{array}$ & \multicolumn{2}{|c|}{$\begin{array}{l}\text { Response } \\
\text { Correct }\end{array}$} & \multicolumn{2}{|c|}{ Incorrect } \\
\hline Bleeding from the vagina & 0 & 56 & 54 & 96.4 & 2 & 3.6 \\
\hline Swelling of the face and hands & 1 & 55 & 50 & 90.9 & 5 & 9.1 \\
\hline Shortness of breath & 0 & 56 & 51 & 91.1 & 5 & 8.9 \\
\hline Emotional highs and lows & 3 & 53 & $\mathbf{1}$ & 1.9 & 52 & 98.1 \\
\hline Resting pulse is over 100 beats/minute & 1 & 55 & $\mathbf{5 3}$ & 96.4 & 2 & 3.6 \\
\hline Back pain along the spine & 21 & 35 & 4 & 11.4 & 31 & 88.6 \\
\hline Back pain along the sides of the spine & 0 & 56 & 54 & 96.4 & 2 & 3.6 \\
\hline
\end{tabular}


Table 4: Action taken by TBA if they encounter a risk sign

\begin{tabular}{|l|l|l|l|l|}
\hline Action & Frequency & Percent & $\begin{array}{l}\text { Valid } \\
\text { Percent }\end{array}$ & $\begin{array}{l}\text { Cumulative } \\
\text { Percent }\end{array}$ \\
\hline Refer to clinic/ hospital & 52 & 92.9 & 92.9 & 92.9 \\
\hline Give water solution and refer to clinic/ hospital & 2 & 3.6 & 3.6 & 96.5 \\
\hline Give glucose and refer to clinic / hospital & 1 & 1.8 & 1.8 & 98.3 \\
\hline Give salt solution and refer to clinic / hospital & 1 & 1.8 & 1.8 & 100.0 \\
\hline Total (n) & 56 & 100.0 & 100.0 & \\
\hline
\end{tabular}

"new bedding is provided". All TBAs (100\%; 56/56) reported that: "instruments and equipment are sterilized"; "the TBA and assistants scrub hands and arms with soap and water"; and "sterile gloves are worn over clean hands" in preparation for birthing.

\section{Labour: Stage One}

All of the TBAs surveyed $(100 \% ; 56 / 56)$ indicated that they take the mother's and baby's pulse, and assess the baby's position within the uterus during stage one. All TBAs surveyed (56/56) also reported that they change the bedding under the mother when it is wet or soiled, they encourage the mother to drink at least one cup of liquid each hour, and to urinate at least every two hours. Ninety-eight percent (55/56) indicated that they assess the mother's temperature (for fever).

Ninety-six percent of TBAs (54/56) reported that they encourage the mother to rest between contractions and to change position every hour, while all TBAs (56/56) provide emotional support to the mother and ensure that she is positioned comfortably for delivery. Ninety-eight percent (55/56) of TBAs indicated that they assess the progress of the birth by performing a vaginal exam. Fifty-seven percent (32/56) of respondents indicated that, "an enema is given" during the birthing stage; and 24\% (12/50) indicated that the mother "requests an enema".

Eighty-eight percent (49/56) also indicated that "womb massage is given" during stage one.

All TBAs surveyed (56/56) indicated that "hands are cleansed before delivery". Fifty-four percent of TBAs (30/ 56) use "soap (and water) and a brush" while $36 \%$ use "soap (and water) only", and 4\% (2/56) use "plain water". Eighty-six percent $(43 / 50)$ of respondents indicated that "vaginal stimulation is provided" at this stage of the birthing process. Fifty-eight percent of respondents (23/40) indicated that this was done with water, while $25 \%$ (10/40) said that "no substance" was used. Five percent of TBAs use "oil" and "oil and water"

\section{Labour: Stage Two}

Ninety-eight percent of TBAs surveyed stated that during stage two of the birthing process, "the birthing area, instruments, mother and TBA are prepared for delivery", and, "the mother's pulse/blood pressure are assessed again". Of those who responded, all (24/24) stated that, "the baby's pulse is assessed again". When given the choice of four birthing positions: hands and knees, half-sitting, squatting and lying on the left side, or, "none of the above"; $27 \%$ $(15 / 56)$ of TBAs indicated that they help the woman to a left side-lying position, while $32 \%$ of TBAs (18/56) responded with, "none of the above". Ninety eight percent (54/55) indicated that the mother is helped to a supine position. All TBAs (56/56) reported that, "the mother is encouraged to use effective breathing for pushing". Seventy-one percent (39/55) of respondents indicated that "the mother's abdomen is pushed or massaged to encourage delivery".

When asked what they use to help prevent vaginal tears, $27 \%(15 / 56)$ of TBAs replied, "by slowing the birth of the head", 25\% (14/56) said, "with vaginal massage" and 14\% $(8 / 56)$ said, "with warm water". Seven percent $(4 / 56)$ of TBAs indicated that they "slow the birth of the head, and perform vaginal massage". All respondents (56/56) reported that, "the TBA is required to remove the cord from around the baby's neck". Ninety-eight percent (54/55) stated that "once the head is delivered, the baby's nose and mouth are cleared". All respondents indicated that "the baby's first shoulder is delivered towards the tailbone" (54/54) and, "the baby is placed with the mother immediately after birth" $(56 / 56)$.

\section{Labour: Stage Three}

All TBAs indicated that once the baby has been delivered, "the TBA delivers the placenta" (54/54); and "the placenta and membranes are checked to ensure they are intact" (52/ 52). When asked "what happens to the placenta after it is delivered?" $24 \%$ (13/54) replied that it is "examined and given to the family/relative/mother to take home." All respondents indicated that "the baby is examined by the TBA for overall health" (55/55); and then, "bathed and dried, wrapped and placed with the mother" (56/56). All respondents also indicated "the mother is encouraged to begin breast feeding within one hour." Thirteen percent of respondents (7/53) stated that, "antibiotic ointment is ap- 
plied to the baby's eyes" and "the baby is given a vitamin K injection".

Sixty percent (32/53) stated that "the [umbilical] cord is cut only once it turns white and stops pulsating" while all TBAs (56/56) indicated that, "the cord is tied off in two places and cut with a sterile instrument." Sixty-six percent (37/56) of TBAs indicated that the umbilical cord is tied with thread that has been treated with alcohol. Eighty percent indicated that the umbilical cord is cut with "a blade", and $82 \%$ (46/56) stated that before use the cutting instrument is treated with alcohol, while $13 \%(7 / 56)$ water that has been boiling for more than 20 minutes. Fifty-nine percent of TBAs indicated that immediately after the cord is cut, the umbilical stump is treated with alcohol (33/56), 21\% (12/56) said that it was treated with "nothing".

Sixty percent (33/55) of TBAs indicated that the mother is given food or medication after delivery; while $38 \%(21 / 55)$ indicated that the newborn is given food or medication after delivery. Ninety-four percent $(51 / 54)$ of TBAs stated that herbal treatments are not given after delivery. When asked, "how many hours does the TBA remain after delivery?" $32 \%$ (17/54) replied " 1 to 2 hours", $30 \%$ (16/54) said " 2 to 3 hours" and $19 \%(10 / 54)$ said " 3 to 5 hours".

Ninety-eight percent (54/55) of the TBAs surveyed indicated that two to six hours after the placenta is delivered, "the mother is shown how to massage the uterus to harden and tighten it", "the TBA bathes and dries the mother" and "the mother's genitals are examined for tears or other problems". All TBAs (55/55) indicated that "the TBA encourages the mother to urinate", and that "the mother is provided with food and liquids". Ninety-six percent (53/55) indicated that "the baby's general appearance is examined", while all TBAs (55/55) stated that "the baby's physical signs are taken (pulse, reflexes);" and 63\% (34/54) of respondents stated "the baby's weight and length are measured". All TBAs (54/54) stated that "the family is given time together".

\section{Post-Partum}

All respondents $(55 / 55)$ indicated that they make a postpartum visit to the client's house, $73 \%(40 / 55)$ indicated that the postpartum visit is made every day for one week. Based on their responses, the following activities are performed by all respondents during this visit: the mother is encouraged to eat nutritious foods (55/55); to rest (55/55) and to stay clean $(55 / 55)$. The mother is also instructed to keep the baby clean, dry and warm (53/53); to keep the umbilical stump clean and dry (53/53); to allow the baby to breast-feed often (54/54); to take the baby for tetanus immunization (55/55) and how to prepare oral re-hydration in case of diarrhoea (55/55). Ninety-six percent (53/55) of TBAs reported that they also perform a ceremonial bath for the baby.

\section{Beliefs of TBAs towards Prenatal, delivery and postnatal care}

When asked why some women deliver small babies, the four most common responses given by the TBAs were: alcohol abuse $(24 \% ; 21 / 86)$; starvation/malnutrition (22\%; $19 / 86)$; poor health of the mother $(20 \% ; 17 / 86)$ and smoking $(19 \% ; 16 / 86)$. The two most common reasons provided for "why some babies die soon after delivery" were: "birthing problems" $(19 \% ; 11 / 58)$ and "poor health of the mother" (17\%; 10/58).

Sixty-eight percent (38/56) of the TBAs surveyed indicated that they had seen a baby born with some kind of deformity. The two most common reasons provided for birth deformities were: "smoking" $(21 \% ; 9 / 42)$, and "drinking alcohol" (17\%; 7/42). Fourteen percent $(6 / 42)$ of respondents said they "don't know". When asked, "why do some women have twins?" $45 \%$ (24/53) said, "It is God's will/a gift or blessing from God"; and 17\% (9/53) said "from generations". Twenty-one percent (11/53) of TBAs stated "I don't know". Responses to the open-ended question, "Why can't some women become pregnant?' included: "using contraception" (24\%; 12/54), "God's will" (11\%; 6/ $54)$, and "doesn't have eggs" (11\%); "small uterus (congenital)" (7\%; 4/54). Seventeen percent $(9 / 54)$ indicated that they did not know.

Eighteen percent of responses to the question, "why do some women decide to have home deliveries?" centred on the availability and ease of access to TBAs (10/56), and the fact that "the mother prefers to deliver at home". Fifteen percent $(8 / 56)$ of responses focused on limited access to area hospitals and clinics; with comments including, "mothers are afraid of hospitals", "hospitals are far away", "hospitals are full" and "clinics do not conduct deliveries". When asked why local women seek their services instead of a physician, $33 \%$ of TBAs (18/55) stated that it is because "TBAs are friendly, caring and good" while 20\% (11/ 55) said that it is because "it saves money (TBAs charge nothing)" and because, "TBAs are always available and nearby".

Ninety-eight percent of TBAs stated that they do give advice to women about birth control. Ninety-three percent $(52 / 56)$ indicated that they could not/would not help if a woman wanted to terminate her pregnancy.

\section{Discussion}

\section{Knowledge and attitudes towards HIV/AIDS}

The fact that all (100\%) TBAs were aware that HIV/AIDS is transmitted through body fluids, such as blood, semen, vaginal fluids and breast milk was very encouraging. The majority (86\%) of TBAs surveyed believed that it was totally impossible to contract HIV/AIDS from sexual intercourse if one uses a condom. Since studies have shown that the condom provides protection in nine (9) out of ten (10) users (Frezieres, Walsh, Nelson, Clark \& Coulson, 1999), this belief indicated that the participants were not aware of this information on condom efficacy, nor that the $100 \%$ protection from the condom cannot be guaranteed but that protection depends on proper and consistent use (http:// www.fda.gov/fdac/features/1998/298 con.html). 
In addition, while the majority of TBAs (98\%) said they were able to identify the common symptoms of AIDS (swelling of glands and fever), a large number $(70 \%)$ also said that one could always tell when someone has AIDS. Contrasting attitudes were identified in the analysis of the HIV/ AIDS Attitudes questionnaire. While the majority of TBAs (93\%) indicated that it was important to care for and be helpful to someone who has AIDS, a large number (63\%) said that they would be upset if they had to care for someone with AIDS. These findings reflect the concern among TBAs of contracting HIV/AIDS.

All TBAs identified that AIDS was caused by a virus, but the majority (70\%) of TBAs also believed that AIDS is God's punishment for living wrong lives. Overall, the TBAs held negative attitudes toward homosexuality, since a large number $(58 \%)$ felt that having sex with someone of the same gender was wrong, and not good for your health $(61 \%)$, and many $(61 \%)$ were uncomfortable with being alone with someone who was known to have sex with people of the same gender. These findings were congruent with the admission from a large number (67\%) of TBAs that the AIDS epidemic has caused them to have negative attitudes toward men who have sex with men.

TBAs' responses differed when responding to questions related to an AIDS patient's right to access to medical/ health care. While a large number $(81 \%)$ indicated that patients with HIV/AIDS had as much right to health care as anyone else, TBAs were divided equally on the issue of spending health care money to help HIV/AIDS patients.

\section{Knowledge, attitudes and beliefs related to prenatal, delivery and postnatal care}

Overall, the TBAs had a broad understanding of prenatal care, and all stages of the birthing process. Positive findings included that the TBAs took care to ensure that the mother was supported physically and emotionally, and that she was comfortable and clean before, during and after she had given birth. Many TBAs ( $86 \%$ ) provided vaginal massage (lubrication) to prevent tearing of the perineum during delivery. In addition to teaching the mother how to massage the uterus after birth (98\%), TBAs also reinforced the mother's need for nutritious food, and provided teaching about rehydration following delivery $(100 \%)$.

Other positive findings were that the baby was bathed and placed with the mother immediately after birth (100\%), and that the TBA encouraged breastfeeding soon after delivery to encourage milk production (100\%). Many TBAs were able to identify complications and referred women freely to hospitals and clinics as appropriate (93\%). TBAs demonstrated an awareness of and respect for culture by handing over the placenta to the mother or family after ensuring that it was complete $(48 \%)$. By reporting and recording every birth $(94 \%)$ they also demonstrate responsibility for their role.

Data from the focus group interview revealed that there is also widespread belief in traditional methods of increasing the likelihood of becoming pregnant and activating labour. These include; "taking "imbiza" (medicine from a traditional healer) to clean the womb", drinking "isihlambezo" to activate labour, consulting a faith-healer (women who examine the womb by inserting fingers to check if it is straight), or taking an enema. These harmful traditional practices were also observed in previous studies and the consensus is that they shoulu be dispelled through training and supervision of TBAs (Asghar, 2001: 56-57; Sahachowdhury, 2000:5).

It was evident from the focus group results that TBAs have a good knowledge of pregnancy and pre-natal care. They use proper practices regarding labour and delivery (including HIV/AIDS prevention), and immediate post-partum care. Where practicable, they appropriately refer complications to nurses, clinics and hospitals, with whom they enjoy a good working relationship. This referral information contrasts with a study done by Jonowitz, Wallace, Araujo \& Araujo, (1985), in North East Brazil, in which inappropriate referrals (low-risk patients) and inappropriately retained mothers (high-risk non-referrals) by TBAs were also observed. The study in Brazil was, however, done through analysis of records in a closely monitored situation whereas the study under review was self-reporting. The participants' knowledge of local traditional beliefs and practices is appropriately combined with their modern training. TBAs are challenged by working in under-serviced, often poverty stricken areas, sometimes travelling long distances (mostly walking), often at night, and usually without being compensated. As the only trained healthcare providers available in some areas, they are respected for the important services they afford the community women.

In conclusion, the findings of this study showed that the TBAs' knowledge of HIV/AIDS was good, as they all knew about its transmission even though they had some misconceptions about other issues, such as the efficacy of condoms and signs and symptoms of the disease. The respondents also showed positive but mixed feelings towards people with HIV/AIDS. The respondents still apply some traditional health practices surrounding pregnancy and labour which have been reported to be harmful. The findings also indicated that some links with the western health care system have been established because the majority referred their clients either to a nurse, doctor, clinic or hospital.

\section{Recommendations}

TBAs should undergo continued training, monitoring and supervision by the department of health. The training could include hygiene and infection control, including information on universal precautions to dispel the TBAs' misconceptions about the possibility of contracting HIV. Furthermore, TBAs should be encouraged to eliminate harmful traditional practices. There has to be cooperation between the western and traditional delivery system through integration of the TBAs into the Primary Health Care system.

Community awareness should be raised about the exist- 
ence of the relationship between these two systems, so that they can freely utilize the TBAs during pregnancy and delivery without the fear of being victimized at the clinic. The community needs to be made aware, though, of the limitations of the TBAs' practice. TBAs need to be supported by the government through well-established referral and transport systems so as to provide their services efficiently. This should include provision of delivery packs, sterilization equipment and disinfection of delivery equipment. In addition, appropriate referral guidelines could be developed, considering idiosyncrasies of the various areas and individuals, for example, culture and literacy levels.

\section{Limitations of the study}

Data collection was self-reporting and the validity and reliability of such reports is often questioned, especially with behaviours or feelings that could be judged to be wrong (Polit \& Hungler, 1995:312). Baseline data was however established for future training of TBAs.

\section{Conclusion}

In conclusion, the findings of this study have indicated that the TBAs can cope well with support from the western health care system. This support should be in the form of recognition, the referral system, provision and maintenance of delivery equipment.

\section{Acknowledgements}

Sincere gratitude is given to the Canadian International Development Agency (CIDA) for funding this Primary Health Care Project for the empowerment of rural women. Special tribute goes to Professor B. Majumdar from McMaster University and Professor L. Uys of the University of Natal for their able leadership in the project partnership.

\section{References}

ASGHAR, RJ 1999: Obstetric complications and role of Traditional Birth Attendants in developing countries. Journal of College of Phvsicians and Surgeons Parkistan. 9 (1): 55-57.

BULTERYS, M.. FOWLER, MG,SHAFFER, N, TIH, PM., GREENBERG, AE, KARITA, E., COOVADIA, H., DE COCK, KM 2002: Role of traditional birth attendants in preventing perinatal transmission of HIV. British Medical Journal 324 (7331): 222-225. http://bmj.com/cgi/content/full/ $\underline{324 / 7331 / 222}$

CHALMERS, B 1990: African Birth: Childbirth in Cultural Transitions. Bersey Publication cc: Riverclub.

CRESWELL, J W 2003: Research design: Qualitative, Quantitative, and Mixed Methods Approaches. $2^{\text {nd }}$ edition. Thousand Oaks: Sage Publications

DAVIES, CY, YIN NU, M, OUM, S \& WAISI, S 1992: A
Study of the Utilization of Traditional Birth Attendants in a Rural Area of North- East Thailand.

http://www.sph.uq.edu.au/acithn/reports/th/92birth.html

DEPARTMENT OF HEALTH 2001: White paper for the transformation of the Health Care System in South Africa, Pretoria: Government Gazette. http://www.polity.org.za/ govdoc/white papers/health.html.

EHLERS, V 2000: Nurses as Advocates between Western and Traditional Health Practices in South Africa. Health SA Gesondheid. 5(2): 29-36.

FREZIERES, RG, WALSH, TL, NELSON, AL, CLARK, VA, \&COULSON, AH 1998: Breakage and Acceptability of Polyurethane Condom: A Randomized, Controlled Study. Family Planning Perspectives 30(2): 73-78.

HABIMANA, P; BULTERYS, M; USABUWERA, P; CHAO, A; \& SAAH, AJ. 2002: A survey of occupational blood contact and HIV infection among traditional birth attendants in Rwanda. http://www.ncbi.nim.nih.gov/entrez/ query.fcgi?cmd=retrieve \&db. .

ht t p://www. mariestopes.org.uk/ traditional birth attendants.html Accessed on 08/06/2001.

http://www.mariestopes.org.uk/case studv1.html Accessed on 08/06/2001.

JONOWITZ, B, WALLACE,S, ARAUJO, G, \& ARAUJO, L 1985: Referrals by Traditional Birth Attendants in Northeast Brazil. American Journal of Public Health. 75(7): 745 748.

KEY, K. \& DENOON, DJ 1995: Researchers Survey Traditional Birth Attendants in Rwanda. AIDS Weekly.7/4/94: $13,2 \mathrm{p}$.

http://globalvgw12.global.epnet.cpm/ deliverv.asp?delivervoption

NEUMAN, W L 1997: Social research methods: Quantitative and Qualitative Approaches. $3^{\text {rd }}$ edition. Boston: Allyn and Bacon.

NORDENBERG, T 1998: Condoms: Barriers to Bad News. (http://www.fda.gov/fdac/features/1998/298 con.html)

POLIT, DF \& HUNGLER, BP 1995: Nursing Research, Principles and Methods. $6^{\text {th }}$ edition. Philadelphia: Lippincott.

PRETORIUS, E 1999: Traditional Healers. South African Health Review. Durban: Health Systems Trust

SAHACHOWDHURY, S 2000: Intranatal Care by Traditional Birth Attendant: A Case Study Approach. The nursing Journal of India, LXXXXI (1).

WALRAVEN, G 2002: Commentary: Involving traditional birth attendants in prevention of HIV transmission needs 
careful consideration. BMJ. 324: January: 224-225)

YATCH, D 1998: Addressing Africa's Health Needs: Time for Strong South African Involvement. South African Medical Journal. 88(2): 127-129. 